\title{
PENGEMBANGAN MODEL PEMBELAJARAN \\ INTERAKSI SOSIAL BAGI PENINGKATAN \\ APRESIASI DAN EKSPRESI SENI PENTAS DI SMA \\ KABUPATEN SUBANG
}

\author{
Dadang Supriatna \\ STKIP Subang \\ dr.dadangsupriatna@gmail.com
}

\begin{abstract}
Development model the study have social interaction for make-up of artistic interest apresiasi of stage in Senior High School Subang regency. Dissertation, Education Indonesia Studies Program. Graduate School of Education University of Indonesia Bandung. Education represent the basin to preserve the science values. Acculturation and competitor enableness educated in education aim to to give the everyday life stock. In course of the needed a teacher giving by word, develop;building willingness, and also develop the potency and competitor creativity educated. Artistic study apresiasi of stage in Senior High School in this time not yet obtained the maximal result. this matter is resulted from by some factor pursuing the efficacy. pursuant to problems is above, this research aim to to develop the study model have social interaction for make-up artistic interest apresiasi of stage in Senior High School. This research apply the method of research and development ( $R \& D$ ). this research population is Senior High School of SeKabupaten Subang. The Subject in this research three senior high school country selected two class, that is class XI and each class selected one class of majors natural science (IPA) and one class of majors social studies (IPS). This subjects in research include;cover the student, teacher of subject of language indonesia, and colleague. To net the research data use the cognate tes for examination of interest of student and tes performance as tes of examination praktik, interview, and observation. analyse the data by qualitative and quantitative. Pursuant to data analysis and test-drive the model concluded that study model have social interaction for artistic improvement apresiasi of stage in Senior High School represent the model which is good to used in artistic study apresiasi of stage this Senior High School. Matter is proven result test-drive 1 mean 65,36, test-drive 2 mean 69,87 , test-drive 3 mean 77,69 that student achievement of pursuant to the test-drive can mount better. Model the study have social interaction to artistic apresiasi of stage represent the very effective study model for can improve the student interest in artistic interest apresiasi of stage.
\end{abstract}

Keywords: Model of Teaching, Students, Stage Art 


\begin{abstract}
ABSTRAK
Pengembangan Model Pembelajaran Interaksi Sosial Bagi Peningkatan Apresiasi dan Ekspresi Seni Pentas Di SMA Kabupaten Subang.Disertasi, Program Studi Pendidikan Bahasa Indonesia, Sekolah Pascasarjana Universitas Pendidikan Indonesia, Bandung. Pendidikan merupakan wadah untuk melestarikan nilai-nilai keilmuan. Proses pembudayaan dan pemberdayaan peserta didik dalam pendidikan bertujuan untuk memberikan bekal kehidupan sehari-hari. Dalam proses tersebut diperlukan guru yang memberikan keteladanan, membangun kemauan, serta mengembangkan potensi dan kreativitas peserta didik. Pembelajaran apresiasi seni pentas di SMA saat ini belum memperoleh hasil yang maksimal. Hal ini diakibatkan oleh beberapa faktor yang menghambat keberhasilan tersebut. Berdasarkan permasalahan di atas, penelitian ini bertujuan untuk memperoleh model pembelajaran apresiasi dan ekspresi seni pentas di SMA. Penelitian ini menggunakan pendekatan penelitian dan pengembangan (Research and Development). Populasi penelitian ini adalah Sekolah Menegah Atas Negeri Se- Kabupaten Subang.Sampel penelitian adalah tiga Sekolah Menengah Atas Negeri dipilih dua kelas, yaitu kelas XI dan masing-masing kelas dipilih satu kelas. Sampel penelitian ini mencakup siswa, guru mata pelajaran bahasa Indonesia,dan rekan sejawat. Untuk menjaring data peneliti menggunakan tes kognitif sebagai pengujian kompetensi siswa dan tes performance sebagai tes pengujian praktik pementasan, wawancara, dan obsevasi.Analisis data dilakukan secara kuantitatif dan kualitatif. Berdasarkan analisis data dan uji coba model disimpulkan bahwa model pembelajaran berinteraksi sosial bagi peningkatan apresiasi seni pentas di SMA merupakan model yang baik untuk digunakan dalam pembelajaran apresiasi seni pentas di SMA. Hal ini terbukti pada uji coba1 rata-rata 65,36, uji coba 2 rata-rata 69,87, uji coba 3 rata-rata 77,69 bahwa prestasi siswa berdasarkan uji coba tersebut rata-rata dapat meningkat dengan baik. Model pembelajaran interaksi sosial apresiasi dan ekspresi seni pentas merupakan model pembelajaran yang sangat efektif untuk meningkatkan kompetensi siswa dalam kompetensi apresiasi seni pentas.Berdasarkan respon guru dan siswa mengenai model tersebut sangat menarik dan memberikan kekhasan untuk lebih akif dan kreatif.
\end{abstract}

Kata Kunci: Model Pembelajaran, Siswa, dan Seni Pentas

\section{A. Pendahuluan}

Pendidikan merupakan wadah untuk melestarikan nilainilai keilmuan. Proses pembudayaan dan pemberdayaan peserta didik dalam pendidikan bertujuan untuk memberikan bekal kehidupan sehari-hari. Dalam proses pendidikan diperlukan guru yang memberikan keteladanan, membangun kemauan, serta mengembangkan potensi dan 
kreativitas

peserta

didik.

ekspresi seni pentas. Model

Pembelajaran adalah proses pembelajaran merupakan pola interaksi peserta didik, guru dan umum perilaku pembelajaran untuk sumber belajar pada suatu lingkungan belajar. Proses pembelajaran perlu direncanakan, dilaksanakan, dinilai, dan diawasi agar terlaksana secara efektif dan efisien. Untuk mencapai keberhasilan dalam kegiatan pembelajaran, terdapat beberapa komponen yang dapat menunjang, yaitu komponen tujuan, komponen materi, komponen strategi belajar mengajar, dan komponen evaluasi.Komponen-komponen tersebut saling berkaitan dan saling mempengaruhi. Keempat komponen pembelajaran tersebut harus diperhatikan oleh guru dalam memilih dan menentukan model-model pembelajaran yang akan digunakan dalam kegiatan pembelajaran.

Model pembelajaran apresiasi dan ekspresi seni pentas akan terlaksana dengan maksimal jika direncanakan berdasarkan berbagai prinsip atau teori sebagai pijakan dalam pengembangan pembelajaran apresiasi dan mencapai kompetensi atau tujuan pembelajaran yang diharapkan. Model pembelajaran dapat dijadikan pola pilihan, artinya para guru boleh memilih model pembelajaran yang sesuai dan efisien untuk mencapai tujuan pembelajaran khususnya untuk guru bahasa Indonesia dalam pembelajaran apresiasi dan ekspresi seni pentas.

Pembelajaran apresiasi dan ekspresi seni pentas diberikan kepada siswa karena banyak manfaat yang dapat diperoleh dalam kehidupan seharihari.Pembelajaran apresiasi dan ekspresi seni pentas pada hakikatnya belajar tentang hidup dan kehidupan, melalui apresiasi dan ekspresi seni pentas manusia akan memperoleh gizi batin sehingga dapat dicerahkan lewat perolehan nilai-nilai yang terkandung di dalam karya sastra. Pada kenyataan di lapangan pembelajaran apresiasi dan ekspresi seni pentas drama belum 
dapat dilaksanakan sesuai dengan harapan kurikulum.

Berdasarkan hasil penelitian terdahulu, Suwarto (2008) menyimpulkan bahwa pembelajaran apresiasi drama, guru mengalami kesulitan yang terletak pada bahan ajar dan beban belajar, alokasi waktu yang kurang dalam pembelajaran drama, dan sumber daya manusia (SDM) guru yang memiliki pemahaman tentang teater yang masih terbatas, siswa yang mempunyai rasa percaya diri dan keberanian yang masih kurang, pemeranan kurang, sarana dan prasarana pembelajaran apresiasi drama kurang.

Selanjutnya Aryani, Hasyim, dan Prayitno (2010) menyimpulkan bahwa proses pembelajaran yang masih didominasi guru, juga dapat menjadi pengaruh yang menyebabkan tingkat apresiasi drama siswa menjadi rendah sebab siswa enggan untuk mengkaji drama. Masih banyak guru yang hanya puas dengan media berupa teks/naskah drama sebagai media untuk mengajarkan drama pada siswanya.Padahal media pembelajaran dapat menentukan kondisi pembelajaran yang terjadi di kelas. Apabila guru menggunakan media yang menarik, maka siswa akan tertarik untuk mengikuti pelajaran, proses belajar-mengajar dapat berjalan lancar, suasana kelas menjadi lebih menarik, menyenangkan, dan pembelajaran dapat berlangsung dengan efektif dan efisien.

Nugroho (2008), Dalam penelitiannya menyimpulkan bahwa pengalaman dan pemahaman guru yang terbatas terhadap teknik bermain drama, sarana pendukung, dan lingkungan kelas yang kurang mendukung bermain drama menghambat siswa dalam pembelajaran apresiasi drama.

Pembelajaran apresiasi sastra di sekolah.Sebagai "agen perubahan dan peradaban", sekolah mestinya bisa dimanfaatkan sebagai ruangan dan media yang strategis untuk mengakarkan sekaligus menguatkan nilai-nilai moral, religi, dan budaya.Namun, secara jujur 
harus diakui, sekolah-sekolah di negeri kita ini sering hanya tampak gedungnya yang megah, tetapi kualitas pembelajarannya "hancur" dan babak belur.Lebih-lebih pembelajaran apresiasi sastra.Para siswa tidak diajak untuk mengapresiasi (memahami dan menikmati) teks-teks sastra yang sesungguhnya, tetapi sekadar menghafalkan namanama sastrawan dan hasil karyanya. Guru dalam memberikan pembelajaran sastra barulah kulit luarnya saja sehingga peserta didik gagal menikmati lezatnya isi dan aroma kandungan nilai dalam karya sastra. Kondisi pengajaran sastra yang semacam itu tidak saja memprihatinkan, tetapi juga telah "membusukan" proses pencerdasan emosional dan spiritual siswa (Baksin, 2008:6-7).

Buruknya mutu pembelajaran apresiasi sastra di sekolah juga tak lepas dari minimnya guru sastra yang memiliki "talenta" dan minat serius terhadap sastra.Apalagi, sastra hanya merupakan mata pelajaran yang "dinunutkan" pada pelajaran bahasa.Lantaran statusnya yang hanya sekadar "nunut", tidak mengherankan jika apresiasi sastra hanya disajikan sambil lalu. Meskipun sastra erat kaitannya dengan bahasa, tetapi proses penyajiannya perlu kreativitas dan model penyajian tersendiri (Baksin, 2008:6).

Keberhasilan pembelajaran apresiasi seni pentas tersebut, dipengaruhi beberapa faktor, yakni: (1) kurikulum, (2) guru, (3) siswa, (4) sarana dan kondisi lingkungan sekitar yang mendukung terlaksananya pementasan yang maksimal. Sebagaimana yang dikatakan oleh Syamsuddin A.R (1985:10) bahwa untuk mengajarkan bahasa dan sastra yang baik, sehingga tercapai penguasaan maksimal yang baik, seorang guru terlebih harus memahami dan mengetahui seluk beluk bahasa dan sastra yang akan diajarkannya.

Berdasarkan uraian di atas diperlukan pengembangan model pembelajaran interaksi sosial bagi peningkatan apresiasi dan ekspresi seni pentas di SMA lebih memberikan motivasi pada guru 
mata pelajaran bahasa Indonesia dan siswa untuk mendapatkan hasil prestasi yang maksimal.

\section{B. Landasan Teori}

Keberhasilan suatu proses pembelajaran diawali dengan perencanaan yang sangat matang. Perencanaan yang dilakukan dengan baik, maka setengah keberhasilan sudah dapat tercapai, setengahnya lagi terletak pada pelaksanaan. Namun demikian, perencanaan yang sudah baik sistematis atau terperinci, jika pelaksanaan proses pembelajaran tidak sesuai dengan perencanaan, maka mungkin sekali akan gagal. Perencanaan dan pelaksanaan pembelajaran belum tentu akan mencapai keberhasilan jika dilakukan sembarangan sehinggga proses pembelajaran kurang menarik, membosankan, tidak merangsang siswa untuk aktif dan kreatif, sehingga tujuan pun tidak tercapai. Oleh karena itu, perencanaan yang baik dan pelaksanaan yang tepat akan menentukan keberhasilan proses pembelajaran.
Perencanaan pembelajaran pada mulanya merupakan suatu ide dari orang yang merancangnya, tentang bentukbentuk pelaksanaan proses pembelajaran yang akan dilaksanakan. Untuk mengkomunikasikan ide tersebut, biasanya dituangkan dalam bentuk perencanaan tertulis. Selanjutnya berdasarkan perencanaan tersebut, diwujudkan dalam pelaksanaan, yaitu dalam proses pembelajaran Stenhouse (Hakim, 2009:1).

Strategi berasal dari kata Yunani strategia yang berarti 'ilmu perang' atau 'panglima perang'. Selanjutnya Hornby mengemukakan bahwa, "strategy is the art of planning operation in war, esp of the movents of armies and navis into favourable positions for fighting; skill in managing any affair. Strategist is person skilled in strategy" Hornby (Kosadi, 1995:1).

\section{Berdasarkan} pendapat tersebut dapat disimpulkan bahwa strategi adalah suatu seni merancang operasi di dalam peperangan, seperti cara-cara 
mengatur posisi atau siasat berperang angkatan darat atau laut. Strategi dapat diartikan pula sebagai suatu keterampilan mengatur suatu kejadian atau hal ikhwal (Kosadi, 1995:1).

Strategi menurut Kemp (Rusman, 2011:132) adalah suatu kegiatan pembelajaran yang harus dikerjakan guru dan siswa agar tujuan pembelajaran dapat dicapai secara efektif dan efisien.Senada dengan pendapatnya Kemp, Dick and Carey (Rusman, 2011) juga menyebutkan bahwa strategi pembelajaran itu adalah suatu perangkat materi dan prosedur pembelajaran yang digunakan secara bersama-sama untuk menimbulkan hasil belajar pada peserta didik atau siswa.Upaya mengimplementasikan rencana pembelajaran yang telah disusun dalam kegiatan nyata agar tujuan yang telah disusun dapat tercapai secara optimal, maka diperlukan suatu metode yang digunakan untuk merealisasikan strategi yang telah ditetapkan.Dengan demikian, bisa terjadi satu strategi pembelajaran menggunakan beberapa metode. Misalnya, untuk melaksanakan strategi ekspositori bisa digunakan metode ceramah sekaligus metode tanya jawab atau bahkan diskusi dengan memanfaatkan sumber daya yang tersedia termasuk menggunakan media pembelajaran. Oleh sebab itu, strategi berbeda dengan metode. Strategi menujukan pada sebuah perencanaan untuk mencapai sesuatu, sedangkan metode adalah cara yang dapat digunakan untuk melaksanakan strategi.

Pendekatan dapat diartikan sebagai titik tolak atau sudut pandang kita terhadap proses pembelajaran. Istilah pembelajaran merujuk kepada pandangan terjadinya suatu proses yang sifatnya masih sangat umum. Kellen (Rusman, 2011) mencatat bahwa terdapat dua pendekatan dalam pembelajaran, yaitu pendekatan yang berpusat pada guru (teacher centered approaches) dan pendekatan yang berpusat pada siswa (student centered approaches). Pendekatan yang berpusat pada guru 
menurunkan strategi pembelajaran langsung (direct instruction), pembelajaran deduktif atau pembelajaran

ekspositori.Sedangkan, pendekatan pembelajaran yang berpusat pada siswa menurunkan strategi pembelajaran inkuriri dan diskoveri serta pembelajaran induktif.

Sedangkan model-model pembelajaran sendiri biasanya disusun berdasarkan berbagai prinsip atau teori pengetahuan. Para ahli menyusun model pembelajaran berdasarkan prinsipprinsip pembelajaran, teori-teori psikologis, sosiologis, analisis sistem, atau teori-teori lain yang mendukung (Joyce \& Weil: 1980). Model tersebut merupakan pola umum prilaku pembelajaran untuk mencapai tujuan pembelajaran yang diharapkan.Joyce \& Weil berpendapat bahwa model pembelajaran adalah suatu rencana atau pola yang dapat digunakan untuk membentuk kurikulum (rencana pembelajaran jangka panjang), merancang bahan-bahan pembelajaran, dan membimbing pembelajaran di kelas atau yang lain (Joyce \& Weil, 1980: 1).Model pembelajaran dapat dijadikan pola pilihan, artinya para guru boleh memilih model pembelajaran yang sesuai dan efisien untuk mencapai tujuan pendidikan tertentu.

Model adalah sesuatu yang menggambarkan adanya pola berpikir.Sebuah model biasanya menggambarkan keseluruhan konsep yang saling berkaitan.Model juga dapat dipandang sebagai upaya untuk mengkonkretkan sebuah teori sekaligus juga merupakan sebuah analogi dan representasi dari variabel-variabel yang terdapat di dalam teori tersebut. Model pembelajaran biasanya menggambarkan langkah-langkah atau prosedur yang perlu ditempuh untuk menciptakan aktivitas pembelajaran yang efektif, efisien, dan menarik (Pribadi, 2011:86).

Arends (Hamruni, 2012:5) menyatakan"The term teaching model refers to a particular approach to instruction that its goals, syntax, environment, and 
management

system".istilah

model pengajaran mengarah pada

suatu pendekatan pembelajaran tertentu termasuk tujuannya, sintaksnya, lingkungan, dan sistem pengelolaannya, sehingga model pembelajaran mempunyai makna yang lebih luas dari pendekatan, strategi, metode atau prosedur. Model pembelajaran adalah suatu perencanaan atau suatu pola yang digunakan sebagai pedoman dalam merencanakan pembelajaran di kelas atau pembelajaran dalam tutorial dan untuk menentukan perangkatperangkat pembelajaran termasuk di dalamnya buku-buku, film, komputer, dan lain-lain.

Soekamto (Hamruni, 2012:6) mengemukakan maksud dari model pembelajaran adalah: "kerangka konseptual yang melukisakanprosedur yang sistematis dalam mengorganisasikan pengalaman belajar untuk mencapai tujuan belajar tertentu dan berfungsi sebagai pedoman bagi para perancang pembelajaran dan para pengajar dalam merencanakan aktivitas belajar mengajar." Hal ini sejalan dengan apa yang dikemukakan oleh Eggen dan Kauchak bahwa model pembelajaran memberikan kerangka dan rah bagi guru untuk mengajar.

Model pembelajaran mempunyai empat ciri khusus yang membedakan dengan strategi, metode atau prosedur. Ciri-ciri tersebut ialah:

a. Rasional teoritik logis yang disusun oleh para pencipta atau pengembangnya.

b. Landasan pemikiran tentang apa dan bagaimana peserta didik belajar (tujuan pembelajaran yang akan dicapai).

c. Tingkah laku pembelajaran yang diperlukan agar model tersebut dapat dilaksanakan dengan berhasil.

d. Lingkungan belajar yang diperlukan agar tujuan pembelajaran itu dapat tercapai. 
1. Dasar

Pemilihan

Pertimbangan

Model

\section{Pembelajaran}

Menurut Rusman (2011:

133) Sebelum menentukan model pembelajaran yang akan digunakan dalam kegiatan pembelajaran, ada beberapa hal yang harus diperimbangkan guru dalam memilinnya, yaitu:

a. pertimbangan terhadap tujuan yang ingin dicapai

b. pertimbangan yang berhubungan dengan bahan atau materi pembelajaran

c. pertimbangan dari sudut peserta didik atau siswa

d. pertimbangan lainnya yang bersifat nonteknis

\section{Ragam Model Pembelajaran} Interaksi Sosial

Menurut Joyce dan Weil (2011) model pembelajaran terbagi atas beberapa model, yaitu (1) model pemrosesan informasi (information processingmodels), (2) model personal (personal models), (3) model sosial (social models), dan (4) model sistem perilaku (behavioral system models), secara garis besar, model cooperative learning atau pembelajaran kooperatif tergolong model sosial.

Kerja kelompok adalah seperangkat strategi intruksional atau pengajaran yang menekankan interaksi siswa-siswa untuk mendukung model-model lain. Kerja kelompok bukanlah sebuah model intruksional perseorangan.Melainkan, sebuah strategi yang dirancang untuk meningkatkan keterlibatan lewat interaksi siswa-siswa saat modelmodel lain digunakan (Eggen dan Kauchak, 2012: 131).

Kerja kelompok dan pembelajaran kooperatif terdiri dari para siswa bekerja sama di dalam kelompok-kelompok cukup kecil (biasanya dua hingga lima) yang bisa diikuti semua orang di dalam tugas yang jelas. Penghargaan kelompok dan tanggungjawab individual sangat berpengaruh terhadap hasil pencapaian pembelajaran kooperatif (Slavin, 2010: 88).

Model interaksi sosial menitikberatkan hubungan yang harmonis antara individu dengan 
masyarakat (learning to life together). Teori Pembelajaran Gestalt dirintis oleh Wertheimer, Koffka dan Kohler (Rusman, 2011:136)

Pokok pandangan Gestalt adalah objek atau peristiwa tertentu akan dipandang sebagai suatu keseluruhan yang terorganisasikan. Makna suatu objek/peristiwa adalah terletak kepada keseluruhan bentuk (gestalt) dan bukan bagianbagiannya. Pembelajaran akan lebih bermakna bila materi diberikan secara utuh, bukan bagian-bagian.

Aplikasi Teori Gestalt dalam Pembelajaran adalah:

a. Pengalaman (insight/tilikan). Dalam proses pembelajaran siswa hendaknya memiliki kemampuan insight, yaitu kemampuan mengenal keterkaitan unsur-unsur dalam suatu objek. Guru hendaknya mengembangkan kemampuan siswa dalam memecahkan masalah dengan insight.

b. Pembelajaran yang bermakna. Kebermaknaan unsur-unsur yang terkait dalam suatu objek akan menujang pembentukan pemahaman dalam proses pembelajaran. Content yang dipelajari siswa hendaknya memiliki makna yang jelas baik bagi dirinya maupun bagi kehidupannya di masa yang akan datang.

c. Perilaku bertujuan. Perilaku terarah pada suatu tujuan. Perilaku disamping adanya kaitan dengan SR-bond, juga terikat erat dengan tujuan yang hendak dicapai. Pembelajaran terjadi karena siswa memiliki harapan tertentu. Sebab itu pemebelajaran akan berhasil bila siswa mengetahui tujuan yang akan dicapai.

d. Prinsip ruang hidup (life space). Dikembangkan oleh Kurt Lewin (teori medan/fild theory). Perilaku siswa terkait dengan lingkungan/medan di mana ia berada. Materi yang disampaikan hendaknya memiliki kaitan dengan situasi lingkungan di mana siswa berada (kontekstual). 


\section{Hasil Penelitian dan}

\section{Pembahasan}

Rancangan model pembelajaran interaksi sosial apresiasi dan ekspresi seni pentas di SMA difokuskan pada apresiasi dan ekspresi seni pentas dengan tujuan untuk meningkatkan apresiasi dan ekspresi seni pentas siswa SMA dalam kompetensi kognitif dan pementasan dalam hal ini peneliti berasumsi bahwa apresiasi dan ekspresi seni pentas dapat ditingkatkan jika proses pembelajaran interaksi sosial digunakan pada pembelajaran apresiasi dan ekspresi seni pentas dalam hal ini harus memperhatikan beberapa langkah kegiatan yang harus dilakukan oleh guru mata pelajaran bahasa Indonesia yaitu pemilihan bahan ajar seni pentas interaksi sosial harus lebih ditekankan berdasarkan dari lingkungan sekitar siswa artinya bahwa pengalaman belajar siswa harus ada keterkaitan dengan bahan ajar yang akan disampaikan sehingga dengan demikian dapat mempermudah siswa dalam belajar, sarana dan prasarana yang tepat dapat menunjang akan turut membantu siswa dalam proses pembelajaran, strategi pembelajaran yang tepat dapat membantu siswa dalam proses pembelajaran dengan baik, evaluasi pembelajaran harus berkaitan dengan bahan ajar yang disampaikan.

Hasil pelaksanaan proses model pembelajaran interaksi sosial apresiasi dan ekspresi seni pentas selama uji coba I ditemukan data-data sebagai berikut. Bahwa, pelaksanaan proses model pembelajaran interaksi sosial apresiasi dan ekspresi seni pentas selama uji coba I telah dilaksanakan sesuai dengan skenario, dan alur pembelajaran model interaksi sosial apresiasi dan ekspresi seni pentas yang disusun dalam bentuk langkah-langkah pembelajaran telah diterapkan oleh guru. Namun, upaya tersebut belum membuahkan hasil yang menggembirakan.Berdasarkan catatan akhir penelitian ini diperoleh data bahwa dalam proses pembelajaran siswa masih 
cenderung bersikap pasif, duduk manis dan hanya mendengarkan. Keterlibatan siswa dalam proses pembelajaran yang diharapkan, belum diperankan. Siswa masih tampak takut, malu, dan kurang percaya diri ketika guru berupaya untuk menggiring keterlibatan merereka dalam proses pembelajaran.

Tabel 1. Keseluruhan Hasil Evaluasi pada Uji Coba I

\begin{tabular}{|c|l|c|c|c|c|c|c|}
\hline No & \multicolumn{1}{|c|}{ Soal } & $\begin{array}{c}\text { SMAN 1 } \\
\text { Subang }\end{array}$ & $\begin{array}{l}\text { SMAN 2 } \\
\text { Subang }\end{array}$ & $\begin{array}{c}\text { SMAN 1 } \\
\text { Pagaden }\end{array}$ & $\begin{array}{c}\text { Jumlah } \\
\cdot\end{array}$ & $\begin{array}{c}\text { Rata- } \\
\text { rata }\end{array}$ & Ket. \\
\hline 1 & Pementasan & 70,15 & 60,15 & 63,80 & 194,10 & 64,70 & Uji Coba \\
\hline 2 & Kognitif & 71,37 & 62,44 & 64,23 & 198,04 & 66,01 & । \\
\cline { 1 - 5 } 3 & $\begin{array}{l}\text { Pementasan } \\
\text { dan Kognitif }\end{array}$ & 70,76 & 61,30 & 64,01 & 196,07 & 65,36 & \\
\hline
\end{tabular}

Berdasarkan catatan akhir penelitian ini ditemukan data-data bahwa siswa mulai menunjukan perkembangan kearah yang sangat positif.Usaha guru melakukan langkah pendekatan secara pribadi kepada siswa telah membuahkan hasil yang cukup memuaskan.Intensitas pertanyaan pancingan yang diberikan oleh guru telah berhasil memancing aktivitas dan kreativitas siswa.Rasa malu, takut dan minder atau kurang.
Percaya diri berangsurangsur dapat dihilangkan.Hal ini ditunjukan oleh banyaknya siswa yang mulai terlibat secara aktif dalam setiap kegiatan guru. Di SMA Negeri tempat penelitian ini dilaksanakan siswa tampak mulai aktif menjawab pertanyaanpertanyaan guru, dan siswa yang lain terlihat mulai simpati terhadap proses pembelajaran yang digelar pada uji coba II ini. Guru tidak henti-hentinya memberikan motivasi kepada siswa, agar siswa benar-benar terlibat aktif dalam pembelajaran apresiasi dan ekspresi seni pentas.

Tabel 2. Keseluruhan Hasil Evaluasi pada Uji Coba II

\begin{tabular}{|c|c|c|c|c|c|c|c|}
\hline No & Soal & $\begin{array}{l}\text { SMAN } 1 \\
\text { Subang }\end{array}$ & $\begin{array}{l}\text { SMAN } 2 \\
\text { Subang }\end{array}$ & $\begin{array}{l}\text { SMAN } 1 \\
\text { Pagaden }\end{array}$ & Jumlah & $\begin{array}{l}\text { Rata- } \\
\text { rata }\end{array}$ & Ket \\
\hline 1 & Pementasan & 70,05 & 70,30 & 68,60 & 208,95 & 69,65 & \multirow{3}{*}{$\begin{array}{c}\text { Uji Coba } \\
\|\end{array}$} \\
\hline 2 & Kognitif & 70,24 & 69,82 & 70,18 & 210,24 & 70,08 & \\
\hline 3 & $\begin{array}{l}\text { Pementasan } \\
\text { dan Kognitif }\end{array}$ & 70,14 & 70,06 & 69,39 & 209,59 & 69,87 & \\
\hline
\end{tabular}

pelaksanaan proses pembelajaran apresiasi dan ekspresi seni pentas menggunakan model interaksi sosial pada uji coba III, baik hasil evaluasi maupun hasil observasi kegiatan guru dan hasil observasi 
kegiatan siswa dapat dilihat dalam tabel berikut.

Tabel 3. Keseluruhan Hasil Evaluasi pada Uji Coba III

\begin{tabular}{|c|l|c|c|c|c|c|c|}
\hline No & \multicolumn{1}{|c|}{ Soal } & $\begin{array}{c}\text { SMAN 1 } \\
\text { Subang }\end{array}$ & $\begin{array}{c}\text { SMAN 2 } \\
\text { Subang }\end{array}$ & $\begin{array}{c}\text { SMAN 1 } \\
\text { Pagaden }\end{array}$ & Jumlah & $\begin{array}{c}\text { Rata- } \\
\text { rata }\end{array}$ & Ket \\
\hline 1 & Pementasan & 80,26 & 79,80 & 70,60 & 230,66 & 76,89 & \multirow{2}{*}{ Uji Coba } \\
\cline { 1 - 5 } 2 & Kognitif & 80,71 & 79,76 & 75,00 & 235,48 & 78,49 & III \\
\cline { 1 - 5 } 3 & $\begin{array}{l}\text { Pementasan } \\
\text { dan Kognitif }\end{array}$ & 80,49 & 79,78 & 72,80 & 233,07 & 77,69 & \\
\hline
\end{tabular}

\section{Pengembangan}

Model

Pembelajaran Interaksi Sosial Bagi Peningkatan Apresiasi

\section{dan Ekspresi Seni Pentas}

Berdasarkan hasil uji coba terbatas dan meluas penilaian pakar, pengguna, dan praktisi dikembangkan model pembelajaran apresiasi dan ekspresi seni pentas sebagai berikut.

Langkah-langkah Kegiatan Model Pembelajaran Apresiasi dan Ekspresi Seni Pentas

a. Tahap Pertama Reading

b. Tahap Kedua Casting

c. Tahap Ketiga Bloking

d. Tahap Keempat Eksploring e. Tahap Kelima

Playing

Model pembelajaran apresiasi dan ekspresi seni pentas akan berhasil jika memperhatikan hal sebagai berikut.

a. Kurikulum

b. Bahan pembelajaran

c. Sarana dan prasarana

d. Faktor guru diperhitungkan mengenai kompetensi yang dimiliki dan pengalaman dalam seni pentas

e. Faktor siswa mengenai bakat, kompetensi, dan pengalaman dalam seni pentas

f. Faktor lingkungan pembelajaran yang mendukung

g. Faktor guru dan siswa yang kreatif dan inovatif

h. Faktor latar belakang kehidupan sosial siswa

i. Faktor latar belakang orang tua siswa

j. Faktor siswa dalam pengembangan nilai rasa, pikir, perbuatan/ekspresi

\section{Kesimpulan}

Hakikat model pembelajaran interaksi sosial bagi peningkatan 
apresiasi dan ekspresi seni pentas

di SMA adalah pembelajaran kooperatif dalam hal ini pembelajaran tidak bertumpu pada interaksi guru dan siswa tetapi lebih menekankan pada lingkungan sekitar sehingga siswa lebih terpacu untuk dapat mengembangkan kompetensi dalam menemukan hasil pembelajaran yang lebih maksimal.

Penelitian pengembangan model pembelajaran interaksi sosial apresiasi dan ekspresi seni pentas di SMA ini dilakukan mulai dari prapenelitan, rancangan model pembelajaran apresiasi dan ekspresi seni pentas, proses pembelajaran dan hasil pembelajaran, serta uji coba model pembelajaran apresiasi dan ekspresi seni pentas

Berdasarkan hasil analisis data dan pembahasan, maka dapat dikemukakan simpulan temuan sebagai jawaban atas rumusan masalah penelitian sebagai berikut.

1. Rancangan model pembelajaran apresiasi dan ekspresi seni pentas dirancang mulai dari persiapan pembelajaran, pelaksanaan pembelajaran dan penilaian pembelajaran interaksi sosial tidak hanya menekankan pada proses pembelajaran yang bersifat kooperatif meliputi kerja kelompok, pertemuan kelas, pemecahan masalah sosial, bermain peran, dan simulasi sosial tetapi lebih menekankan interaksi siswa dengan siswa, guru dengan siswa pada pembelajaran di kelas..

2. Model pembelajaran interkasi sosial bagi peningkatan apresiasi dan ekspresi seni pentas di SMA sangat efektif seperti tampak dari hasil uji coba yang menunjukkan bahwa prestasi siswa dalam apresiasi dan ekspresi seni pentas hasilnya meningkat. Hal ini berdasarkan dari hasil uji coba 1 nilai rata-rata keseluruhan 65,36, hasil uji coba 2 nilai ratarata keseluruhan 69,87, dan hasil uji coba 3 nilai rata-rata keseluruhan 77,69.

3. Model pembelajaran interaksi sosial bagi peningkatan 
apresiasi dan ekspresi seni pentas di SMA menunjukkan perbedaan yang signifikan dibandingkan dengan pembelajaran yang tanpa menggunakan model

pembelajaran interaksi sosial.

\section{DAFTAR PUSTAKA}

Achmad, Kasim. 1990. Pendidikan Seni Teater. Jakarta: Departemen Pendidikan dan Kebudayaan

Aminuddin. 2002. Pengantar Apresiasi Karya Sastra. Bandung: Sinar Baru Algensindo.

Anirun, Suyatna. 1998. Menjadi Aktor. Bandung: Rekamedia Multiprakarsa.

Aryani, Hasyim, dan Prayitno. 2010. "Pembinaan dan Pementasan Teater Sekolah serta Fungsinya dalam Pembelajaran Apresiasi Drama di Kelas XI SMA Pangudiluhur Surakarta." Jurnal.Universitas

Muhamadiah Surakarta.

Asrori, Mohammad. 2009. Psikologi Pembelajaran. Bandung: Wacana Prima.

Baksin, Askurifai. 2008. Aplikasi Praktis Pengajaran Sastra. Bandung: Pribumi Mekar

Damono, Sapardi Djoko. 1983. Kesusastraan Indonesia Modern. Jakarta: Gramedia
Depdikbud.1988. Kamus Besar Bahasa Indonesia. Jakarta: Balai Pustaka

Dewojati, Chayaningrum. 2010. Drama Sejarah, Teori, dan Penerapannya. Yogyakarta: Gajah Mada University Press. Eggen dan Kauchak. 2012. Strategi dan Model Pembelajaran. Jakarta: Indeks

Endraswara, Suwardi. 2011. Metode Pembelajaran Drama. Yogyakarta: CAPS

Hakim, Lukmanul. 2009. Perencanaan Pembelajaran. Bandung: Wacana Prima.

Hamruni. 2012. Strategi Pembelajaran. Yogyakarta: Insan Madani.

Hamzah, A. Adjib. 1985. Pengantar Bermain Drama. Bandung: Rosda.

Harymawan. 1986. Dramaturgi. Bandung: Rosdakarya.

Hasanuddin. 1996. Drama Karya dalam Dua Dimensi.

Bandung: Angkasa

Hasanuddin, 2007. Ensiklopedi Sastra Indonesia. Bandung: Titian IImu

Hidayat, Kosadi. 1995. Strategi Belajar Mengajar Bahasa Indonesia. Bandung: Binacipta

Ismet, Adang. 2007. Seni Peran. Bandung: Kelir.

Jaeni.2012. Komunikasi Estetik Menggagas Kajian Seni dari Peristiwa Komunikasi 
Pertunjukan. Bogor: IPB

Press.

Joyce, Bruce and Weil. 2011. Models of Teaching.

Yogyakarta: Pustaka Pelajar

Kosasih.2008. Apresiasi Sastra Indonesia. Jakarta: Nobel

Lesmana, Otong. 2007. Pengetahuan Dasar Seni Teater. Bandung: Mapan Luxemburg. 1987. Tentang Sastra. Muiderberg: Intermasa.

Nugroho. 2009. "Peningkatan Kemampuan Memerankan Tokoh Drama dengan Menggunakan Teknik Bermain Drama Rendra. Pada Siswa Kelas XI IPA 1 di SMA Negeri Kerejo".Tesis.

Nurgiyantoro, Burhan. 2007. Teori Pengkajian Fiksi. Yogyakarta: Gadjah Mada University Press.

Nurgiyantoro, Burhan. 2011. Penilaian Pembelajaran Bahasa. Yogyakarta: BPFEYogyakarta

Pradopo, Djoko. 2003. Beberapa Teori Sastra, Metode Kritik, dan Penerapannya. Yogyakarta: Pustaka Pelajar.

Pribadi, A. Benny. 2011. Model Desain Sistem Pembelajaran. Jakarta: Dian Rakyat.

Putra, Angkasa Bintang. 2012. Drama Teori dan Pementasan. Yogyakarta: Citra Aji Parama.

Rendra. 1979. Tentang Bermain Drama. Jakarta: Pustaka Jaya.
Restianti.2009. Peningkatan Mutu Pendidik dalam Mengajarkan Drama. Bandung: Citra Praya. Rusman. 2011. Model-Model Pembelajaran

Mengembangkan

Profesionalisme

Guru. Jakarta: Rajagrafindo Persada.

Rusyana, Yus. 1982. Metode Pengajaran Sastra. Bandung: Gunung Larang

Rusyana, Yus. 1984. Bahasa dan Sastra dalam Gamitan Pendidikan. Bandung: Bulan Bahasa.

Saini, K.M dan Sumarjo Jakob. 1988. Apresiasi Kesusastraan. Jakarta: Gamedia

Saptaria, El. Rikrik. 2006. Akting. Bandung: Rekayasa Sains.

Sardjono, Partini. 2005. Pengkajian Sastra. Jakarta: PT. Garamedia Pustaka Utama.

Siswanto, Wahyudi. 2008. Pengantar Teori Sastra. Jakarta: PT. Garasindo.

Slavin, E. Robert. 2010. Cooperative Learning Teori Riset dan Praktik. Bandung: Nusa Media.

Sufanti, Main. 2010. Strategi Pengajaran Bahasa dan Sastra Indonesia. Surakarta: Yuma Pustaka.

Sugihastuti. 2011. Teori Apresiasi Sastra. Yogyakarta: Pustaka Pelajar. 
Sugiyono. 2012. Metode Penelitian Kualitatif dan R\&D. Bandung: Alfabeta.

Suprijono, Agus. 2011.

Cooperative Learning Teori dan Aplikasi Paikem.

Yogyakarta: Pustaka Pelajar.

Suroso. 1999. Ikhtisar Seni Sastra.

Surakarta: Tiga Serangkai

Suwarto. 2008. "Pembelajaran Apresiasi Drama di Madrasah Aliyah Negeri 1 Seragen." Tesis.Program Pascasarjana Universitas Sebelas Maret Surakarta.

Stanton, Robert. 2007. Teori Fiksi. Yogyakarta: Pustaka Pelajar

Syamsuddin AR. 1985. Sanggar

Bahasa Indonesia. Jakarta: UT Jakarta

Syamsuddin AR. 1992. Studi Wacana Teori, Analisis, Pengajaran. Bandung: Geger Sunten

Tarigan. 1995. Dasar-Dasar Psikosastra. Bandung: Angkasa

Tarigan. 2011. Prinsip-Prinsip Dasar Sastra. Bandung: Angkasa.

Teeuw. 1983. Membaca dan Menilai Sastra. Jakarta: PT Gramedia

Uno, B. Hamzah. 2011. Model Pembelajaran Menciptakan proses Belajar Mengajar yang Kreatif dan Efektif. Jakarta: Bumi Akasara.

Wellek dan Warren. 1989. Teori Kesusastraan. Jakarta: PT. Gramedia. 